\title{
DIMENSIONS OF SERVICE QUALITY IN GLAMPING
}

\author{
Ana-Marija Vrtodušić Hrgović \\ Josipa Cvelić Bonifačić \\ Ines Milohnić
}

https://doi.org/10.20867/tosee.05.14

\begin{abstract}
Purpose - Service quality plays an important role in improving quality and competitiveness in glamping, an innovative and novel form of accommodation in campsites. Therefore, this paper strives to present the dimensions of service quality in glamping from the perspective of two target groups: guests and campsite managers.

Methodology - Research was based on a structured questionnaire, designed especially for each target group (guests and campsite managers). The study included 120 managers and 130 guests. Surveys were conducted in 2017 and 2018 using an on-site questionnaire for managers and both an on-site and online questionnaire for guests. The data were analysed using methods of descriptive and inferential statistics.

Findings - Research results indicate that managers and guests alike attach importance to the quality elements of glamping service and glamping accommodation facilities. Both target groups agree that friendly staff, professional staff and cleanliness have the greatest role in ensuring glamping service quality, and attractive and well-maintained natural environment, equipment and fittings, and innovative and appealing appearance, in glamping accommodation quality. Results also show that the importance scores given by managers are somewhat higher than those given by guests, in all quality elements that were rated with regard to glamping service and glamping facilities. Contribution - This study makes a contribution to theory and application. From a theoretical perspective, the study contributes by broadening the literature by identifying quality elements in glamping from the perspective of guests and campsite managers. From an application perspective, the results of research contribute by highlighting the quality elements that are important to guests and that should be taken into consideration when designing a product/service as well as in the service provision process.
\end{abstract}

Keywords glamping. service quality, dimensions, glamping services, glamping accommodation

\section{INTRODUCTION}

Over the past decade, camping has been experiencing a transformation through the implementation of novel and innovative accommodation increasingly referred to as glamping. Although "glamping" has become an umbrella term for numerous types of accommodation units and equipment, there is still no consensus regarding its unique qualitative features. Because opinions about what constitutes glamping, and what its common features are, differ widely and from author to author, there is still no agreement either in Europe or in Croatia concerning the characteristics of glamping accommodation units, the types of such units, and the characteristics and levels of service quality in glamping. Official documents, stipulating the quality levels of campsites in Croatia, define glamping as a type of accommodation unit and a type of glamping equipment but give no qualitative ranking. Furthermore, there is no classification or categorisation of glamping accommodation units. Consequently, there are no recognised or universally 
ToSEE - Tourism in Southern and Eastern Europe, Vol. 5, pp. 773-785, 2019

A.-M. Vrtodušić Hrgović, J. Cvelić Bonifačić, I. Milohnić: DIMENSIONS OF SERVICE QUALITY IN ...

accepted and classified types of glamping accommodation units or glamping equipment, nor have the characteristics of glamping service quality been defined.

Glamping is a trend that rejuvenates and redesigns the camping product, and is directly connected to innovative and novel forms of accommodation in campsites, creating a symbiosis of hotels and camping. This innovative form of accommodation in campsites is focused on improving quality and increasing competiveness. In achieving that service quality in glamping plays an important role. Therefore, the aim of this paper is to present the dimensions of service quality in glamping from the perspective of guests and campsite managers. An overview of the previous literature indicates that only a few studies have focused on the issues of service quality in glamping what additionally represent a motive for this research.

\section{QUALITY SERVICE IN GLAMPING}

The term "quality" comes from the Latin word "qualitas", meaning character, a property, and refers to the excellence, high value, merit, characteristic and capability of something. (Klaić 1990, 774). Deming argues that the consumer/customer is the most important part of the production process and that quality should be aimed at the needs of consumers, present and future. (Deming 2000, 5). Juran, in one of his definitions, refers to quality as those properties of a product that fulfil customers' needs thus ensuring customer satisfaction. (Juran in Juran, Godfrey, Hoogstood, Schilling 1999, 2.1.) The starting point of Crosby's definition of quality is also the customer because for Crosby quality means "conformance to requirements". (Crosby 1996, 21). Oakland also defines quality in a similar way, implying that quality is "meeting the customer's requirements (needs and expectations)". (Oakland 2003, 4). The importance of customers and their requirements is also embedded in the definition of quality according to ISO 9000:2015 Quality Management System - Fundamentals and Vocabulary, which states that quality is the "degree to which a set of inherent characteristics of an object fulfils requirements". (ISO 9000:2015,47).

Service quality continues to be one of the major competitive factors in tourism and hospitality. Hence, it is imperative for tourism and hotel managers to ensure, measure and evaluate service quality.

A service is actually the action of doing work for someone. (Oxford Dictionary 1993, 766). It is the output of an organization with at least one activity necessarily performed between the organization and the customer. (ISO 9000:2015, 53). Service refers to the entire bundle of tangibles and intangibles in a transaction with a significant service component. Service is an activity or benefit one party can offer to another that is essentially intangible and does not result in the ownership of anything. Production may or may not be tied to a physical product (Kotler et al. 1998 in Kandampully et al. 2001, 13). In addition to intangibility, the main characteristics of services are perishability, inseparability of production and consumption and heterogeneity. (Kandampully et. al, $2001,8)$ 
ToSEE - Tourism in Southern and Eastern Europe, Vol. 5, pp. 773-785, 2019

A.-M. Vrtodušić Hrgović, J. Cvelić Bonifačić, I. Milohnić: DIMENSIONS OF SERVICE QUALITY IN ...

The final assessment of service quality relies not only on the outcome of the service but also on the service process, that is the quality of the interpersonal interaction between customer and provider (Kandampully et al. 2001, 24). There are many dimensions of service quality. According to Parasuraman, Zeithaml and Berry, those dimensions are (Parasuraman et al. 1988, 23): Reliability - ability to perform services dependably and accurately; Tangibles - appearance of physical facilities, equipment, personnel and communication materials; Responsiveness - willingness to help customers and provide prompt service; Assurance - knowledge and courtesy of employees and their ability to inspire trust and confidence; Empathy - caring, individualized attention the firm provides to customers.

Grönroos related perceived (experienced) quality to the technical and functional dimension of service provision. Technical quality refers to the outcome, that is, WHAT was provided in the service process, whereas functional quality refers to HOW it was provided. Both of these dimensions affect a company's reputation. According to Grönroos, technical quality is essential but, on its own, it is not enough to achieve a higher level of service quality. He considers that functional quality has the more important role, providing that the standards referring to technical quality have been met. (Grönroos 1984 in O'Neill, 2001, 161). Lehtinen and Lehtinen argue there is yet another dimension essential in ensuring service quality. They note that service quality has three dimensions. The first has a physical aspect and involves the physical (tangible) elements of services; the second has an economic aspect and refers to a company's reputation; and the third has an interactive aspect resulting from the employee-customer relationship (Reisinger, 2001 in Kandampully et. al. 2001, 24).

Guests perceive service quality in different ways. Two distinct variables influence their perceptions: customer expectations and service standards. (Kandampully et al. 2001, 51) Perceived service quality reflects the difference between guests' expectations and the actual services performed (Parasuraman et al. in Kandampully 2001, 53) People, processes and physical evidence are choreographed to focus the customers' experience of quality service (Kandampully 2001, 69).

"Customer expectations are beliefs about service delivery that function as standards or reference points against which performance is judged. Because customers compare their perceptions of performance with these reference points when evaluating service quality, thorough knowledge about customer expectations is critical to services marketers" (Zeithaml et al., 2003, 60).

The service product/package is why a customer; client or guest comes to the organization in the first place. The second component of the guest experience is the setting of the environment in which the experience takes place. The third part of the guest experience is the service delivery system including the human components and the physical production process and the information systems and techniques that help deliver the service to the customer. (Ford et al. 2012, 11). Service quality is important to service providers because it has a direct effect on guest satisfaction and, in turn, on business performance. 
ToSEE - Tourism in Southern and Eastern Europe, Vol. 5, pp. 773-785, 2019

A.-M. Vrtodušić Hrgović, J. Cvelić Bonifačić, I. Milohnić: DIMENSIONS OF SERVICE QUALITY IN ...

To be able to manage the guest experience requires understanding guests who are in the target market and this includes the use of traditional demographic breakdowns (age, gender) and guest locations, and psychographic breakdowns (how they feel, their attitudes, beliefs, values and what kind of experience they need, want and expect from the hospitality organisation). Hospitality organisations should find the capabilities (knowledge, skills and abilities) needed to co-produce the guest experience (Ford et al. 2012, 9).

The challenge for hospitality organisations is to anticipate guest expectations as accurately as possible and then meet and exceed them. (Ford et. al. 2012, 18).

In promoting camping as a high-quality form of holiday-making, it is the chief task not only of managers but also of key organisations in tourism to ensure campsite service quality. For example, the German Camping Association underlines that its first task is to ensure and promote quality in campsites. (Günther and BVCD, 2017). Quality has become pivotal to services in tourism and camping alike, while glamping has become a new paradigm in tourism. (Rebocho, B. and Correria, A. 2017).

A vital factor in achieving campsite guest satisfaction is ensuring that service quality meets the guests' expectations. Hence, it is important to determine the dimensions of campsite service quality and their effect on the process of choosing a campsite. In that context, this research focuses on dimensions of service quality in campsites, particularly with regard to glamping.

The elements of campsite service quality in general and glamping service in particular are still under-researched. For example, a study on a sample of 38 families suggested that key elements of the camping experience include nature, social interaction and comfort/convenience and that the most common associated meanings are restoration, family functioning, experiencing nature, special places, self-identity, social interaction and children's learning. (Garst et al. 2010, 90). A qualitative narrative analysis of web reviews by glamping tourists, in-depth interviews with managers and a survey of glamping guests have shown that service quality in glamping is multidimensional and includes five facets: tangibles, staff, nature-based experiences, food and activities. (Brochado, Pereira 2017, 82).

Today it seems that glamping is blurring the boundaries between top-quality hotels and top-quality campsites with regard to service content and quality by providing innovative opportunities for a stay in the outdoors. (UTM, 2017). On the whole, it appears that camping is shifting towards greater comfort, luxury, sustainability and individuality. (Moehrle, 2018).

\section{CAMPSITE QUALITY EVALUATION}

In Europe as well as in Croatia, quality ranking is commonly carried out through institutional and non-institutional campsite categorization systems. (Milohnić, Vrtodušić Hrgović \& Cvelić Bonifačić, 2017). Institutional framework is defined by the Ordinance on the Classification and Categorisation of Hospitality Facilities in the Group 
ToSEE - Tourism in Southern and Eastern Europe, Vol. 5, pp. 773-785, 2019 A.-M. Vrtodušić Hrgović, J. Cvelić Bonifačić, I. Milohnić: DIMENSIONS OF SERVICE QUALITY IN ...

"Campsites" (MINT 2016), the quality of campsites is expressed using a 2-star to 5-star system. Camping rest areas are not categorised.

In Croatia, campsites can also be organised within the framework of households and may not have more than 10 accommodation units (Ordinance on the Classification and Categorisation of Facilities Providing Hospitality Services in Households (unofficial final draft); Official Gazette 9/16); Amendments (Official Gazette 54/16); Rectification (Official Gazette 61/16); Amendments (Official Gazette 69/17). Such campsites are categorised according to a 2-star to 5-star system (after http://www.mint.hr/User DocsImages/160725_pravilnik_kateg_domac_edit.pdf). Camping rest areas are not categorised.

Family-run farms can also establish campsites, the quality of which is expressed using a 2-sun to 4-sun system (Ordinance on the Classification and Categorisation of Facilities Providing Hospitality Services on Family-run Farms (Official Gazette 54/16); Amendments (Official Gazette 69/17) http://narodne-novine.nn.hr/clanci/sluzbeni/ dodatni/440707.pdf

As of 2018, a total of 192 camps, comprising 74392 accommodation units and capable of accommodating 215337 persons, were categorised in Croatia.

Table 1: Number of categorised campsites in Croatia by county and stars

\begin{tabular}{|c|c|c|c|}
\hline County & $\begin{array}{l}\text { Total number of } \\
\text { campsites }\end{array}$ & $\begin{array}{l}\text { Total number of } \\
\text { accommodation } \\
\text { units }\end{array}$ & $\begin{array}{c}\text { Campsite } \\
\text { accommodation } \\
\text { capacities }\end{array}$ \\
\hline $2 *$ & 64 & 15877 & 43626 \\
\hline Istria & 17 & 8015 & 21688 \\
\hline Primorje-Gorski Kotar & 10 & 2356 & 5736 \\
\hline Lika-Senj & 3 & 139 & 417 \\
\hline Zadar & 15 & 2707 & 7904 \\
\hline Šibenik-Knin & 3 & 620 & 1860 \\
\hline Split-Dalmatia & 9 & 1255 & 3666 \\
\hline Dubrovnik-Neretva & 7 & 785 & 2355 \\
\hline $3 *$ & 69 & 26894 & 79111 \\
\hline Istria & 18 & 14623 & 42695 \\
\hline Primorje-Gorski Kotar & 15 & 6224 & 18486 \\
\hline Lika-Senj & 1 & 136 & 408 \\
\hline Zadar & 12 & 1355 & 3984 \\
\hline Šibenik-Knin & 8 & 1697 & 5073 \\
\hline Split-Dalmatia & 6 & 1561 & 4606 \\
\hline Dubrovnik-Neretva & 7 & 676 & 2028 \\
\hline Karlovac & 2 & 622 & 1831 \\
\hline $4 *$ & 56 & 30703 & 89846 \\
\hline Istria & 20 & 17127 & 50140 \\
\hline Primorje-Gorski Kotar & 8 & 4641 & 13138 \\
\hline Lika-Senj & 1 & 2018 & 6054 \\
\hline Zadar & 10 & 3880 & 11640 \\
\hline Šibenik-Knin & 2 & 1159 & 3477 \\
\hline Split-Dalmatia & 6 & 1177 & 3523 \\
\hline
\end{tabular}


ToSEE - Tourism in Southern and Eastern Europe, Vol. 5, pp. 773-785, 2019 A.-M. Vrtodušić Hrgović, J. Cvelić Bonifačić, I. Milohnić: DIMENSIONS OF SERVICE QUALITY IN ...

\begin{tabular}{|c|c|c|c|}
\hline County & $\begin{array}{c}\text { Total number of } \\
\text { campsites }\end{array}$ & $\begin{array}{c}\text { Total number of } \\
\text { accommodation } \\
\text { units }\end{array}$ & $\begin{array}{c}\text { Campsite } \\
\text { accommodation } \\
\text { capacities }\end{array}$ \\
\hline Dubrovnik-Neretva & 5 & 459 & 1152 \\
\hline Karlovac & 2 & 136 & 408 \\
\hline Krapina Zagorje & 1 & 53 & 159 \\
\hline Zagreb & 1 & 53 & 155 \\
\hline $5^{*}$ & 3 & 918 & 2754 \\
\hline Istria & 1 & 143 & 2325 \\
\hline Trimorje-Gorski Kotar & 2 & 775 & 215337 \\
\hline
\end{tabular}

Source: by the authors according to data of the Ministry of Tourism, March 2019.

The terms "glamping home" and "glamping equipment" are explained in paragraphs 8 and 9 of Article 14 of the Ordinance on the Classification and Categorisation of Hospitality Facilities in the Group "Campsites".

Article 36 of the Ordinance stipulates campsite capacity and the share of individual accommodation units. Accordingly, of a campsite's overall capacity expressed by the number of accommodation units, $70 \%$ should provide accommodation to guests/campers in basic accommodation units (camping pitch and/or plot). Campsite buildings may account for the remaining $30 \%$ of accommodation units. Mobile homes or glamping homes can occupy a maximum of $40 \%$ of basic accommodation units. Paragraph 8 of Article 36 stipulates that mobile homes and glamping homes may be placed on 50\% of the basic accommodation unites providing that individually they do not exceed $40 \%$ of the campsite's capacity.

There is still no single system for the evaluation, classification and control of campsite quality at the European level. Quality system implementation is in the domain of national state organisations, while automobile organizations, camping guide publishers and travel organizers have embraced the role of the protectors of consumers/campers in Europe. The best known non-institutional systems for testing campsite quality in Europe are carried out by:

- ADAC - results published in the guidebook ADAC Camping \& Caravaning Führer https://campingfuehrer.adac.de/campingfuehrer/so-bewerten-wir.php

- $\quad$ ANWB - results published in the guidebook ANWB Campinggids https://www.anwb.nl/kamperen

- $\quad$ ACSI - results published in the guidebook Campingführer Europa (https://www.eurocampings.co.uk/)

In addition to the above evaluation systems, there are also many other commerciallybased and marketing-motivated evaluation systems (Top Camping Europe, Leading Campings of Europe etc.). The German Automobile Club ADAC stands out among automobile clubs. Over the years, ADAC has developed a unique and comprehensive campsite quality evaluation system. Evaluation is conducted mostly through inspections in campsites. Results for 2019, encompassing 5,500 campsites, were published in two editions: Nordeuropa and Südeuropa. The 1,300 pages of the Südeuropa edition present 2,900 campsites in 19 countries. (ADAC, 2018). 
ToSEE - Tourism in Southern and Eastern Europe, Vol. 5, pp. 773-785, 2019

A.-M. Vrtodušić Hrgović, J. Cvelić Bonifačić, I. Milohnić: DIMENSIONS OF SERVICE QUALITY IN ...

Among the European countries, Croatia is ranked second in overall campsite quality. In certain elements of quality, however, it is ranked considerably lower. For example, Croatia holds fifth place for bathroom facility quality and only seventh place for plot quality.

In its introduction to presenting Croatian campsites, the 2019 ADAC guide states that improvements in quality and willingness to invest have in recent years paved the road to greater tourism development. A significant number of camps in Istria and along the northern Dalmatian coast provide services and facilities capable of meeting the demand of even the most discerning guests and in no way do their offerings lag behind those of their West Mediterranean competitors. (ADAC, Campingfuehrer Sued Europa, 2018).

The 2019 ADAC guide looks at a total of 109 campsites in Croatia. It indicates that the quality of Croatian campsites grew by $3 \%$ in 2019 . Growth was recorded in all elements of evaluation, except for one: facilities/services for leisure and animation registered a $9 \%$ drop in quality.

The ADAC Superplatz label was awarded to the following camps in Croatia: Aminess Maravea (Novigrad), Lanterna (Tar-Poreč), Omišalj and Baška (Krk Island), Straško (Pag Island), Zaton (Zadar), Krk (Krk Island), Valalta and Val Saline (Rovinj) and Šimuni (Pag Island).

Today, in addition to quality being measured by institutions, it is increasingly being reviewed by campsite guests on websites. Based on their personal experiences, guests award a campsite with a certain number of stars. Such websites are TripAdvisor or the Camping.info portal that rates 22,788 campsites across Europe. (Camping.info 2019).

A number of non-institutional evaluation systems of campsite quality are also in place in Croatia. The most important is the Croatian Camping Union's initiative called Croatia's Best Campsites, which is carried out with the aim of improving the quality of campsite services. A national prize called "Tourism Flower - Quality for Croatia" is awarded based on the results of this evaluation system. In addition to this project, there is also an evaluation system for small campsites united under the OK Camps brand. (http://www.camping.hr/hr/ok-mini-camps). Croatian campsites are also involved in some European initiatives related to specific quality elements. One such initiative is ECOCAMPING. (http://www.ecocamping.net/)

The importance of camping can be seen by the number of overnights realized in campsites. Together, all campsites can accommodate a total of 253,091 guests. (eVisitor) About $40 \%$ of campsite accommodation falls into the 4-star and 5-star categories. In 2018 , campsites accounted for 19,252,215 overnights (+1.34\% in relation to 2017) and the average length of stay was 6.6 days ( $-2 \%$ in relation to 2017). In the same year, the annual occupancy rate in campsites was $21 \%$ (unchanged relative to 2017). Out of the total number of guests, $22 \%$ made arrangements through agencies and $78 \%$ made arrangements independently. (KUH, 2019). 
ToSEE - Tourism in Southern and Eastern Europe, Vol. 5, pp. 773-785, 2019 A.-M. Vrtodušić Hrgović, J. Cvelić Bonifačić, I. Milohnić: DIMENSIONS OF SERVICE QUALITY IN ...

\section{RESEARCH METHODOLOGY AND RESULTS}

In accordance with the research goals, a survey was conducted based on a structured questionnaire designed for campsite managers and guests. The questionnaire was designed on the basis of papers in which glamping attributes were studied from the perspective of guests (Brochado \& Periera 2017; Leci Sakačova 2013) and on the basis of proposals of camping experts (Croatian Camping Union).

The respondents were asked to evaluate the importance of the elements (characteristics/dimensions) of glamping service and the features of glamping accommodation using a Likert scale $(1$ - extremely unimportant, 5 - extremely important). The sample included campsite managers (120) and campsite guests (130) surveyed in 2017 and 2018. Multiple choice questions were used in order to analyse the importance of glamping service elements and glamping accommodation features. The data were analysed using methods of descriptive and inferential statistics and were processed by the IBM SPSS Statistics 23 software.

The survey among guests was conducted by field and online surveys in the period from 25 July 2018 to 15 October 2018. The sample consists of a total of 130 respondents. Almost a third of the respondents are female (67.4\%), nearly half belong to the $36-45$ age group (41.5\%) and roughly half have a monthly income of $€ 2001$ to $€ 5000(45.2 \%)$ More than $70 \%$ of respondents are from Germany.

The importance of glamping service and glamping accommodation elements as perceived by a total of 120 campsite managers, mostly in Istria (40.0\%) and the Kvarner region $(27.5 \%)$, was also investigated.

To determine whether any differences exist in the perceptions of guests and campsite managers, the respondents were asked to rate the importance they attribute to certain glamping service elements and glamping facility quality elements.

Results expressed as average scores given by the two groups of respondents are presented below.

Table 2: Elements of glamping service quality

\begin{tabular}{|r|c|c|c|c|c|}
\hline \multirow{2}{*}{ No. } & \multirow{2}{*}{ Element } & \multicolumn{2}{|c|}{ MANAGERS } & \multicolumn{2}{c|}{ GUESTS } \\
\cline { 3 - 6 } & & MEAN & SD & MEAN & SD \\
\hline 1 & Friendly staff & $\mathbf{4 . 8 0}$ & .442 & $\mathbf{4 . 5 6}$ & .921 \\
\hline 2 & Professional staff & $\mathbf{4 . 7 3}$ & .482 & $\mathbf{4 . 4 9}$ & .915 \\
\hline 3 & Cleanliness & $\mathbf{4 . 6 6}$ & .632 & $\mathbf{4 . 5 4}$ & 1.033 \\
\hline 4 & Escorted to facility & $\mathbf{4 . 2 5}$ & .709 & $\mathbf{2 . 7 8}$ & 1.436 \\
\hline 5 & Food and drinks delivery & $\mathbf{3 . 7 7}$ & 1.137 & $\mathbf{2 . 7 7}$ & 1.408 \\
\hline
\end{tabular}

Source: Author's research

When evaluating glamping service, both guests and managers gave high scores to "Friendly staff", "Professional staff" and "Cleanliness". The scores given by managers, however, were slightly higher than those of guests. 
ToSEE - Tourism in Southern and Eastern Europe, Vol. 5, pp. 773-785, 2019 A.-M. Vrtodušić Hrgović, J. Cvelić Bonifačić, I. Milohnić: DIMENSIONS OF SERVICE QUALITY IN ...

Table 3: Elements of glamping facility quality

\begin{tabular}{|c|c|c|c|c|c|}
\hline \multirow{2}{*}{ No. } & Element & \multicolumn{2}{c|}{ MANAGERS } & \multicolumn{2}{c|}{ GUESTS } \\
\cline { 3 - 5 } 1 & $\begin{array}{c}\text { Attractive and well-maintained natural } \\
\text { environment of the glamping facility (view, } \\
\text { horticulture, well-kept surroundings, } \\
\text { spacious plot) }\end{array}$ & $\mathbf{4 . 8 0}$ & .547 & $\mathbf{4 . 4 2}$ & .866 \\
\hline 2 & $\begin{array}{c}\text { Equipment and fittings in the glamping } \\
\text { facility (bathroom, furniture, tableware, etc.) }\end{array}$ & $\mathbf{4 . 6 9}$ & .534 & $\mathbf{3 . 9 8}$ & 1.287 \\
\hline 3 & $\begin{array}{c}\text { Innovative and appealing appearance of the } \\
\text { glamping facility }\end{array}$ & $\mathbf{4 . 5 9}$ & .618 & $\mathbf{3 . 7 9}$ & 1.224 \\
\hline 4 & $\begin{array}{c}\text { Level of comfort of the glamping facility } \\
\text { (equipment, appearance, spaciousness) }\end{array}$ & $\mathbf{4 . 5 9}$ & .722 & $\mathbf{4 . 0 1}$ & 1.129 \\
\hline 5 & $\begin{array}{c}\text { Location of the glamping facility (directly by } \\
\text { the sea, lake, forest, etc.) }\end{array}$ & $\mathbf{4 . 5 4}$ & .703 & $\mathbf{4 . 3 1}$ & 1.049 \\
\hline
\end{tabular}

Source: Author's research

The same applies to the quality elements of glamping facilities where managers attributed slightly higher importance to these elements than did guests. Managers gave higher scores to glamping facility quality elements, with the most important element being "Attractive and well-maintained natural environment", followed by "Equipment and fittings", "Innovative and appealing appearance", "Level of comfort" and "Location". While guests also ranked "Attractive and well-maintained natural environment" in first place, they rank "Location" second, and "Level of comfort" third. Guests see "Equipment and fittings" as being somewhat less important and gave the lowest score (3.79) to "Innovative and appealing appearance".

Results show that managers gave higher scores to all elements in relation to glamping service and accommodation, indicating that relative to guests they attach greater importance to these elements. To examine whether there are any statistically significant differences between campsite managers and campsite guests with regard to their understanding of glamping service and glamping facility quality elements, independent sample t-tests were performed on source data.

Table 4: Perception of glamping service by guests and managers (t-test)

\begin{tabular}{|c|c|c|c|c|}
\hline No. & Variable & t-value & df & p \\
\hline v1 & Cleanliness & -.997 & 146,943 & .321 \\
\hline v2 & Food and drinks delivery & -5.513 & 175,122 & $\mathbf{. 0 0 0}$ \\
\hline v3 & Escorted to facility & -8.946 & 124,124 & $\mathbf{. 0 0 0}$ \\
\hline v4 & Friendly staff & -2.299 & 122,266 & $\mathbf{. 0 2 3}$ \\
\hline v5 & Professional staff & -2.294 & 126,905 & $\mathbf{. 0 2 3}$ \\
\hline
\end{tabular}

Source: Author's research

An analysis of t-test results points to statistically significant differences in variables 2, 3, 4 and 5. The t-test result of the variable "Food and drinks delivery" is -5.513 , the degrees of freedom are 175,122 and the level of error is $p=.000$. With regard to the variable "Escorted to facility", the t-test result is -8.946 ; the degrees of freedom, 124,124; and the level of error, $\mathrm{p}=.000$. The t-test value of the variable "Friendly staff" is -2.299 , the 
ToSEE - Tourism in Southern and Eastern Europe, Vol. 5, pp. 773-785, 2019

A.-M. Vrtodušić Hrgović, J. Cvelić Bonifačić, I. Milohnić: DIMENSIONS OF SERVICE QUALITY IN ...

degrees of freedom are 122,266 and the level of error is .023 . The value of the t-test of "Professional staff" is -2.294 , the degrees of freedom are 126,905 and the level of error is .023. Results show that the quality elements, ranked from first to third place by both groups of respondents, were assessed as being very important by managers and important by guests. An independent t-test demonstrated that these differences are statistically significant.

Results of t-test analysis for glamping facilities show statistically significant differences between variables $1,2,3$ and $5(\mathrm{p}<0,05)$.

Table 5: Perception of glamping facility by guests and managers (t-test)

\begin{tabular}{|c|c|c|c|c|}
\hline No. & Variable & t-value & df & p \\
\hline v1 & $\begin{array}{c}\text { Attractive and well-maintained natural } \\
\text { environment of the glamping facility }\end{array}$ & -3.996 & 226 & $\mathbf{. 0 0 0}$ \\
\hline v2 & $\begin{array}{c}\text { Equipment and fittings in the glamping facility } \\
\text { v3 }\end{array}$ Innovative and appealing appearance of the & -5.423 & 214 & $\mathbf{. 0 0 0}$ \\
\hline v4 & Llamping facility & -6.170 & 211 & $\mathbf{. 0 0 0}$ \\
\hline v5 & Level of comfort of the glamping facility & -4.385 & 155,527 & $\mathbf{. 0 0 0}$ \\
\hline
\end{tabular}

Source: Author's research

Results indicate that with regard to glamping service quality both campsite managers and guests attach the greatest importance to "Friendly staff", "Professional staff" and "Cleanliness", although the ratings given by managers are higher than those given by guests. The conducted t-test shows that these differences are statistically significant as well. Concerning glamping facility quality, managers assess all elements as being very important (scores are higher than 4.5), whereas the scores given by guests range around and above 4. "Attractive and well-maintained natural environment" has a score of 4.42, while the scores for "Equipment and fittings in the glamping facility" and "Innovative and appealing appearance" are somewhat lower (3.98 and 3.79, respectively). These differences in the perceptions of managers and guests are also statistically significant. The higher scores given by managers can be viewed from a positive perspective, suggesting that managers are aware of the quality elements important to guests, in particular with regard to friendly and qualified staff, cleanliness, appealing and wellmaintained natural environment, and glamping facility equipment. This presents a good precondition to glamping quality improvement. 
ToSEE - Tourism in Southern and Eastern Europe, Vol. 5, pp. 773-785, 2019

A.-M. Vrtodušić Hrgović, J. Cvelić Bonifačić, I. Milohnić: DIMENSIONS OF SERVICE QUALITY IN ...

\section{CONCLUSION}

Results of research conducted in this paper show that:

- Croatian legal and tourism-related regulations recognise glamping as a type of mobile accommodation unit in campsites as well as a type of glamping equipment and, as such, define glamping and stipulate capacities.

- The survey concerning glamping service elements/dimensions conducted among guests and managers points to differences in how individual elements of quality are perceived. For example, both managers and guests see "Friendly staff" as the most important qualitative feature of glamping service, while guests give second place to "Cleanliness" and managers, to "Professional staff".

- $\quad$ There are interesting differences in the way managers and guests perceive glamping accommodation quality. Both groups rank "Attractive and well-maintained natural environment" in first place, while "Location" is ranked second by guests, and "Equipment and fittings", by managers. Guests give fifth place to "Innovative and appealing appearance" and managers, to "Location".

It can be concluded from the conducted research that the key dimensions of glamping accommodation quality are an attractive and well-maintained natural environment (view, horticulture, well-kept surroundings, spacious plot), the location of the facility and the facility's equipment and fittings. Key dimensions of glamping service quality are friendly staff, cleanliness, and professional staff. Trendy glamping services, such as food and drinks delivery, being escorted to the facility and speed of service delivery, play a less important role. Considering that the survey was conducted among a population of current campers, it can be concluded that, also in the case of glamping, campers attach importance to traditional values.

By identifying quality elements in the glamping service provision process, the paper contributes to expanding the existing literature dealing with this research question.

An understanding of the quality elements of glamping service and glamping accommodation facilities that are important to guests can contribute to designing products/services that are in accordance with guest requirements. In particular, these elements should be taken into consideration when designing/developing products/services. By incorporating the perspectives of campsite managers and guests into the context of the perceived importance of glamping service quality elements, this paper expands previous research and provides a solid basis for future studies. Further research involving a wider range of guests will be needed to identify the trends in glamping service quality development.

\section{ACKNOWLEDGEMENT}

This paper is an output of the science project Glamping - a Factor of Campsite Quality. This research has been financially supported by the University of Rijeka, for the projects ZP UNIRI 5/17. 
ToSEE - Tourism in Southern and Eastern Europe, Vol. 5, pp. 773-785, 2019 A.-M. Vrtodušić Hrgović, J. Cvelić Bonifačić, I. Milohnić: DIMENSIONS OF SERVICE QUALITY IN ...

\section{REFERENCES}

ADAC. (2018, December), “ADAC. Campingfuehrer 2019”, https://www.adac.de/der-adac/ueber-uns-se/news /campingfuehrer-2019/ (Retrieved February 21, 2019)

ADAC. (2019), "Campingfuehrer Suedeuropa 2019”, Muenchen: ADAC Medien und Reise GmbH.

ADAC. (2018, December), "ADAC. Campingfuehrer 2019”, https://www.adac.de/der-adac/ueber-uns-se/ news/campingfuehrer-2019/ (Retrieved February 21, 2019)

Brochado, A., Prereira, C., (2017), "Comfortable experiences in nature accommodation: Perceived service quality in Glamping”, Journal of Outdoor Recreation and Tourism, Vol. 17, pp. 77-83. doi: https://doi.org/10.1016/j.jort.2017.01.005

BVCD. (2019), "Campingplaetze in Deutschland 2019" from Der Bundesverband der Campingwirtschaft in Deutschland: https://www.bvcd.de/der-verband/der-verband.html (Retrieved February 28, 2019)

Camping.info (2019, January), www.camping.info: https://en.camping.info/ (Retrieved January 14, 2019)

Crosby, P.B. (1996), "Kvaliteta je besplatna”, Treće izdanje, Privredni vjesnik and Binoza Press, Zagreb.

Deming, W.E. (2000), "Out of the Crisis", The MIT Press, Cambridge.

Ford, R.C., Sturman, M.C., Heaton, P.C., (2012), Managing Quality Services in Hospitality How Organizations Achieve Excellence in the Guest Experience, Delma Cengageg Leraning, NY.

Garst, B.A., Williams, D.R., Roggenbuck, J.W., (2010), "Exploring Early Twenty-First Century Developed Forest Camping Experiences and Meanings", Leisure Sciences, Vol. 32, pp. 90-107, doi: https://doi.org/10.1080/01490400903430905

Günther, C., and BVCD. (2017, November), 11. Kongress KUH-a Šibenik 2019, from "The development of the German camping industry in the past years", https://www.camping.hr/hr/clanovi?newsid=22234 (Retrieved February 25,2019)

HRN EN ISO 9000:2015 "Sustavi upravljanja kvalitetom - Temeljna načela i terminološki rječnik”, 2017. (ISO 9000:2015 Quality Management System - Fundamentals and Vocabulary)

Strategija razvoja turizma RH do 2020, Zagreb: NN 55/2013.

Juran, J.M., (1999), "How to think about quality”, in: Juran, J.M., Godfrey,A.B., Hoogstoel, R.E., Schilling, E.G. (Ed.), Juran's Quality Handbook, Fifth Edition, McGraw-Hill, New York.

Kandampully, J., Mok, C., Sparks, B., (2001), (Ed.), Service Quality Management in Hospitality, Tourism and Leisure, The Haworth Hospitality Press, New York.

Kotler, P., Wong, V., Saunders, J., Armstrong, G. (2006), Osnove marketinga, Mate/Zagrebačka škola ekonomije i managementa, Zagreb.

Klaić, B. (1990), Rječnik stranih riječi, Nakladni zavod Matice hrvatske, Zagreb.

KUH. (2019, January), Newsletter 1-2019, Predstavljen njemačaki vodič kampova ADAC 2019, Kamping udruženje Hrvatske.

Milohnić, I., Vrtodušić Hrgović, A., Cvelić-Bonifačić, J., (2017),"Quality as a Competitive Advantage of Campsites", 17th International Scientific Conference "Globalization and its Socio-economic Consequences", Zilina: University of Zilina, pp. 1582-1589.

Moehrle, M. (2018), "Glamping frisst Camping”, CampingImpulse, 4.

The Oxford Dictionary for the Business World, (1993), Oxford University Press, New York.

Oakland, J.S. (2003), Total Quality Management - text with cases, Third Edition, Elsevier Butteworth Heinemann, Oxford

O'Neill, M., (2001), "Measuring Service Quality and Customer Satisfaction”, in: Kandampully, J., Mok, C., Sparks, B. (Ed.), Service Quality Management in Hospitality, Tourism and Leisure, The Haworth Hospitality Press, New York.

Parasuraman, A., Zeithaml, V., \& Berry, L. (1988), "Servqual: A Multiple-Item Scale for Measuring Consume Perceptions of Service Quality", Journal of Retailing, Vol. 64, No. 1, pp. 12-40.

Parasuraman, A., Zeithaml, V.A., Berry, L.L. (1994), "Alternative scales for measuring service quality: A comparative assessment based on psychometric and diagnostic criteria", Journal of Retailing, Vol. 70, No. 3, pp. 201-230. doi: https://doi.org/10.1016/0022-4359(94)90033-7.

Reisinger, Y. (2001), "Concepts of Tourism, Hospitality and Leisure Services", in Kandampully, J., Mok, C., Sparks, B. (Ed.), Service Quality Management in Hospitality, Tourism and Leisure, The Haworth Hospitality Press, New York.

Ministarstvo Turizma (2016), Pravilnik o razvrstanju i kategorizaciji ugostiteljskih objekata iz skupine Kampovi, http://narodne-novine.nn.hr/clanci/sluzbeni/2016_06_54_1409.html (Retrieved January 2019)

UTM. (2017, November), “Glamping”, Ugostiteljstvo i turizam, Zagreb: UTM.

Zeithaml, V.A., Bitner, M.J. (2003), Services Marketing Integrating Customer Focus Across the Firm, McGraw-Hill, NY. 
ToSEE - Tourism in Southern and Eastern Europe, Vol. 5, pp. 773-785, 2019

A.-M. Vrtodušić Hrgović, J. Cvelić Bonifačić, I. Milohnić: DIMENSIONS OF SERVICE QUALITY IN ...

Ana-Marija Vrtodušić Hrgović, PhD, Associate Professor

University of Rijeka

Faculty of Tourism and Hospitality Management

Department of Quality and Controlling

Primorska 42, 51410 Opatija, Croatia

Phone: +385-51-294182

E-mail: anamariv@fthm.hr

Josipa Cvelić Bonifačić, PhD, Assistant Professor

University of Rijeka

Faculty of Tourism and Hospitality Management

Primorska 42, 51410 Opatija, Croatia

Phone: +385-51-294685

E-mail: jcvelic@fthm.hr

Ines Milohnić, PhD, Full Professor

University of Rijeka

Faculty of Tourism and Hospitality Management

Department of Management

Primorska 42, 51410 Opatija, Croatia

Phone: +385-51-294685

E-mail:imilohni@fthm.hr 